\title{
Modifikasi Proses Pengolahan Kopi Arabika Menggunakan Metode Honey Process
}

\section{Modification of Arabica Coffee Processing Using Honey Process Method}

\author{
Hazfri Dalimunthe ${ }^{1}$,Dina Mardhatilah ${ }^{1,2} \bowtie$, Maria ulfah $^{1}$ \\ ${ }^{1}$ Program Studi Teknologi Hasil pertanian, Institut pertanian Stiper Yogyakarta \\ ${ }^{2}$ Sensory Bean, Coffee Processing, Magelang \\ *Komunikasi Penulis, email: dina@instiperjogja.ac.id \\ DOI:http://dx.doi.org/10.23960/jtep-l.v10i3.317-326 \\ Naskah ini diterima pada 17 Desember 2020; revisi pada 9 April 2021; \\ disetujui untuk dipublikasikan pada 4 Agustus 2021
}

\begin{abstract}
The amount of mucilage can be adjusted according to the washing intensity. The level of ripeness of the coffee fruit is also directly proportional to the mucilage constituent components. Optimally ripe coffee cherries have a higher sugar, protein, lipid and water content than raw coffee cherries. So that research is needed to determine the effect of washing intensity and level of ripeness of coffee cherries on the characteristics of the resulting taste of coffee. The research design used was a complete two-factor block design. The first factor is the intensity of washing mucilage that sticks to the surface of the coffee beans; 2 times washing, 1 time washing, without washing. The second factor is the level of ripeness of the coffee cherries; raw coffee cherries, optimally ripe coffee cherries, past ripe coffee cherries. The analyzes were carried out, namely water content, ash content, total sugar content, $\mathrm{pH}$ value, Brix, and organoleptic test using the SCAA cupping method. The results of this study indicate that washing intensity affects the Brix value, water content, total sugar content, and $p H$. Whereas in the second factor, the level of ripeness of the coffee fruit affects the Brik value, water content, total sugar content, and $p H$. This study also showed that there was a correlation between washing intensity and the level of ripeness of the coffee cherries and the preference of the panelists. The non-washing treatment (black honey) and the optimal level of ripeness were the most preferred by the panelists, all coffees produced from this study met SNI 01-3542-2004.
\end{abstract}

Keywords: arabica characteristics, honey process, maturity level, washing intensity

\begin{abstract}
ABSTRAK
Jumlah mucilage dapat diatur dengan intensitas pencucian. Tingkat kematangan buah kopi juga berbanding lurus terhadap komponen penyusun mucilage. Rancangan penelitian yang digunakan adalah rancangan blok lengkap dua faktor. Faktor pertama yaitu intensitas pencucian mucilage yang menempel pada permukaan biji kopi; 2 kali pencucian, 1 kali pencucian, tanpa pencucian. Factor kedua yaitu tingkat kematangan buah kopi; buah kopi mentah, buah kopi matang optimal, buah kopi lewat matang. Analisis yang dilakukan yaitu kadar air, kadar abu, kadar gula total, nilai $\mathrm{pH}$, brix, serta uji organoleptik yaitu dengan metode cupping SCAA. Hasil penelitian ini menunjukkan intensitas pencucian mempengaruhi nilai Brix, kadar air, kadar gula total, dan pH. Sedangkan tingkat kematangan buah kopi berpengaruh terhadap nilai Brik, kadar air, kadar gula total, dan pH. Penelitian ini juga menunjukkan bahwa ada korelasi antara intensitas pencucian dan tingkat kematangan buah kopi terhadap kesukaan panelis. Perlakuan tanpa pencucian (black honey) dan tingkat kematangan optimal adalah yang paling disukai oleh panelis dengan score 8 (sangat suka), semua kopi yang dihasilkan dari penelitian ini memenuhi SNI 01-3542-2004.
\end{abstract}

Kata Kunci: intensitas pencucian, karakteristik arabik, proses honey, tingkat kematangan

\section{PENDAHULUAN}

Di era Third Wave Coffee yang dimulai pada tahun 2015 , konsumen menuntut informasi yang lebih transparan tentang proses pengolahan kopi hingga kopi tersebut berasal dari daerah mana. Bagaimana biji kopi tersebut di proses, hingga muncul istilah single origin (Ottencoffee.co.id, 
2015). Secara garis besar metode pengolahan kopi terbagi menjadi dua yaitu pengolahan basah dan pengolahan kering atau biasa disebut proses natural. Pengolahan kopi secara natural membutuhkan waktu yang cukup panjang 5560 hari dikarenakan buah kopi dikeringkan utuh dengan kulitnya tanpa melalui proses pengupasan (Suharyanto, 2020). Kopi yang diolah melalui proses natural menghasilkan rasa buah-buahan dan memiliki kompleksitas rasa yang tinggi serta memiliki harga yang lebih mahal dibandingkan kopi dari proses pengolahan lainnya. proses madu dapat di gunakan sebagai solusi untuk menghasilkan kopi dengan citarasa mendekati kopi proses natural tetapi waktu prosesnya jauh lebih singkat (CQI, 2019).

Proses pengolahan madu dilakukan dengan pengupasan kulit buah kopi yang bertujuan untuk mempercepat proses pengeringan, namun lapisan mucilage kopi tetap dipertahankan yang bertujuan agar selama proses pengeringan asamasam organik yang dihasilkan dari fermentasi tersebut terserap oleh biji kopi menghasilkan rasa fruity khas buah-buahan dan kompleksitas rasa yang tinggi menyerupai kopi yang diproses natural. lapisan lendir (mucilage) mengandung $84,2 \%$ air, $8,90 \%$ protein, $4,10 \%$ gula, $0,90 \%$ asam pektat, $0,70 \%$ abu (Mulato dan Suharyanto, 2012). Menurut Madigan dan Martinko (1997), Bakteri Asam Laktat (BAL) selain merombak pektin juga diketahui merombak glukosa menjadi asam laktat selama proses fermentasi berlangsung. Settanni et al. (2005) juga menemukan hal yang sama bahwa selama fermentasi berlangsung beberapa strain bakteri asam laktat merombak gula yang terkandung di dalam mucilage menjadi asam laktat, asam asetat, kaproat, asam format, yang dapat menambah citarasa asam pada seduhannya. Beberapa jenis khamir seperti $S$. cereviseae yang berperan selama fermentasi biji kopi juga mampu menghasilkan etanol seperti yang diungkapkan oleh Harsono et al. (2015).

Kinerja mikrobia dipengaruhi oleh ketersediaan substrat seperti sukrosa, air, protein, pectin dan lipid yang terkandung pada mucilage, sehingga jumlah mucilage pada biji kopi akan mempengaruhi citarasa kopi yang dihasilkan. Tingkat kematangan buah kopi juga memegang peranan penting terhadap citarasa kopi yang dihasilkan, kompleksitas senyawa yang terdapat didalam buah kopi berbanding lurus dengan tingkat kematangan buah kopi (Mulato dan Suharyanto, 2012). Sukrosa merupakan gula sederhana yang terkandung di dalam daging buah kopi, sukrosa merupakan salah satu komponen penting. Kadar gula akan meningkat dengan cepat selama proses pematangan buah yang dapat dikenal dengan adanya rasa manis. Tingkat kematangan buah kopi dan intensitas pencucian dapat mempengaruhi banyaknya mucilage dan kandungan dari lapisan mucilage maupun biji kopi itu sendiri. Perlakuan Black honey sama sekali tidak mengurangi lapisan mucilage pada buah kopi yaitu tanpa pencucian yang baru saja terkupas, Red honey mucilage di hilangkan sedikit sehingga mucilage sebesar $85 \%$ atau dengan 1 kali pencucian, dan Yellow honey mucilage di sisakan sebesar $50-70 \%$ atau dengan 2 kali pencucian.

Rancangan penelitian yang digunakan yaitu Rancangan Blok Lengkap (RBL), terdiri dari dua faktor yaitu variasi intensitas pencucian dan variasi tingkat kematangan buah kopi dengan 2 kali ulangan untuk mengetahui karekteristik fisik, kimia dan organoleptik kopi yang dihasilkan.

\section{BAHAN DAN METODE}

Secara garis besar yang akan dilakukan pada penelitian ini meliputi: pengolahan kopi dengan proses madu dengan pengelompokkan tingkat kematangan buah kopi dengan cara sortasi berdasarkan warna kulit buah kopi dan variasi intensitas pencucian pada biji kopi yang sudah dikupas. Analisis kimia kandungan biji kopi, uji organoleptic berdasarkan SCAA.

\subsection{Pengolahan Kopi Dengan Proses Madu}

Buah kopi yang baru dipetik dari perkebunan kopi rakyat di daerah Windusabrang, Wonolelo Sawangan Kabupaten Magelang Jawa tengah disortasi menurut berat jenisnya dengan cara perambangan didalam air, diambil buah kopi yang tenggelam kemudian dipisahkan berdasarkan tingkat kematangannya; buah kopi mentah, buah kopi matang, buah kopi lewat matang yang dipisahkan berdasarkan perbedaan warna kulit buah kopi. Masing-masing buah 

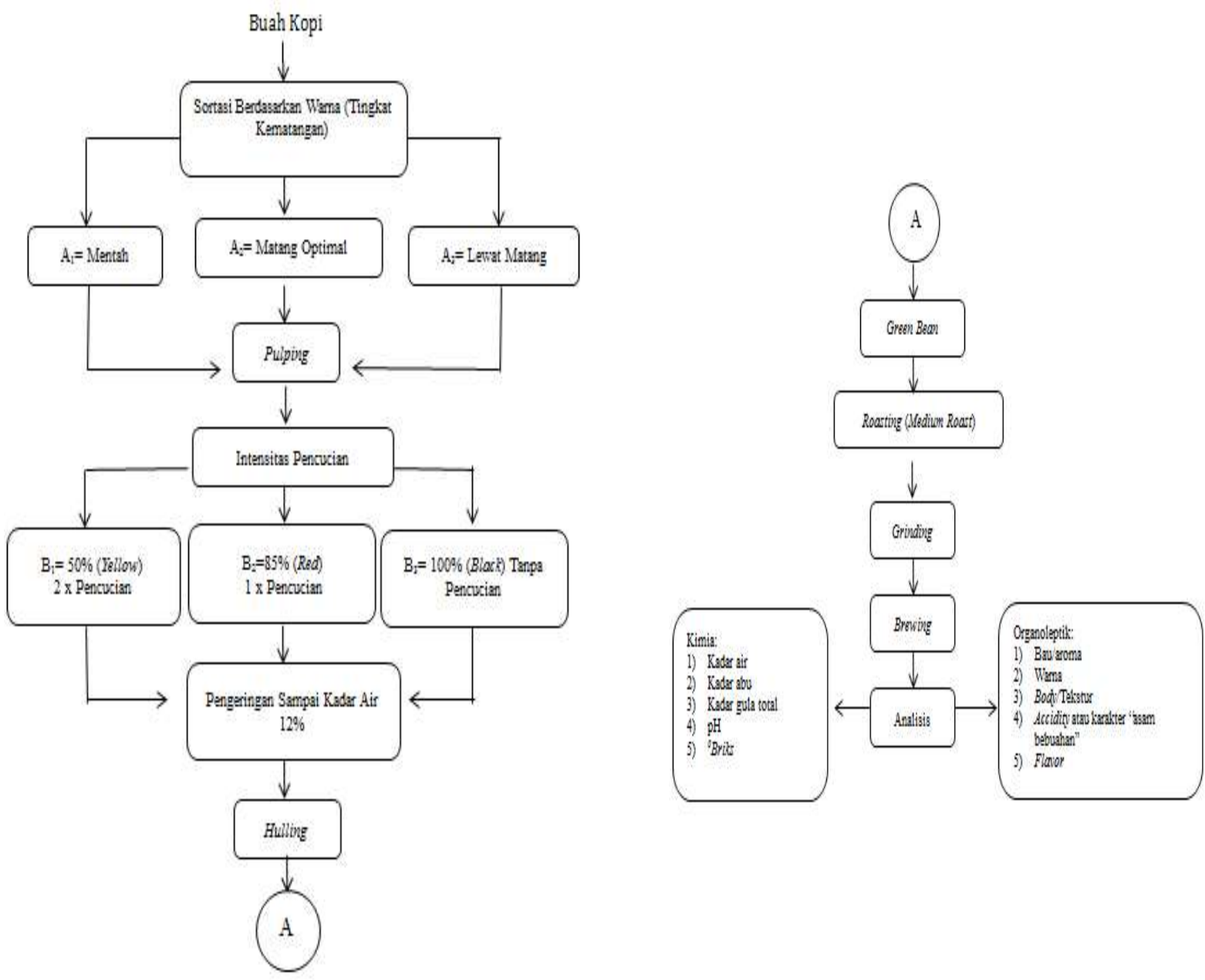

Gambar 1. Diagram Alir Penelitian

kopi di timbang sebanyak $5 \mathrm{~kg}$ kemudian buah kopi di kupas menggunakan mesin pulper. Biji kopi yang sudah terkupas kemudian divariasikan intensitas pencuciannya meliputi; tanpa pencucian, pencucian 1 kali, pencucian 2 kali.biji kopi kemudian biji kopi dijemur menggunakan matahari selama 10 hari diatas meja pengeringan dengan suhu 26-36 Celsius hingga mencapai kadar air $12 \%$, setelah kadar air biji kopi turun $12 \%$ kemudian dilakukan proses resting kurang lebih 1 bulan setelah itu pengupasan kulit tanduk (Hulling) untuk mendapatkan biji kopi beras (green bean) kemudian kopi beras disangrai menggunakan mesin sangrai merek Gene CBR 101 dengan level sangrai medium, dan dilakukan pengecilan ukuran menggunakan grinder merek Latina grind size 4 , bubuk kopi yang didapatkan kemudian dilanjutkan untuk di analisis kimia dan uji organoleptic. Diagram alir penelitian disajikan dalam Gambar 1.

\subsection{Analisis Kimia Biji Kopi 2.2.1. Penentuan Kadar Air}

Disiapkan sampel bubuk kopi arabika sebanyak 1-2 gram pada cawan porselen yang telah dikeringkan dan diketahui berat kosongnya, kemudian sampel dikeringkan dengan cara memasukkan ke dalam oven selama 3 jam menggunakan suhu $105^{\circ} \mathrm{C}$. Setelah $3 \mathrm{jam}$, sampel kemudian diletakkan ke dalam desikator selama 15 menit kemudian sampel ditimbang kembali untuk mengetahui bobot setelah pemanasan, langkah ini di ulang hingga didapatkan berat konstan. Penentuan Kadar Air menggunakan SNI 01-2891-1992.

\subsubsection{Kadar Abu}

Menentukan Kadar abu menggunakan metode gravimetri mengikuti (SNI 01-2907-2008 (Badan Standardisasi Nasional, 2008). Disiapkan sampel sebanyak $2 \mathrm{~g}$, kemudian sampel diabukan menggunakan tanur pada suhu $300^{\circ} \mathrm{C}$ 
selama 1,5 jam, lalu suhu dinaikkan menjadi $550^{\circ} \mathrm{C}$ selama 2,5 jam. Sampel kemudian dimasukkan ke dalam desikator dan ditimbang bobotnya.

\subsubsection{Penentuan Nilai ${ }^{0} b r i k x$}

Menyiapkan buah kopi segar, kemudian bagian kulit luar buah kopi ditusuk sehingga cairan mucilage dari dalam buah kopi dapat keluar. Buka penutup alat refractometer yang berbentuk prisma kemudian letakkan 2-3 tetes sampel di permukaan prisma lalu ditutup. Arahkan prisma ke sumber cahaya kemudian lihat dari sisi kaca teropong akan terlihat jelas batas daerah berwarna biru dan putih yang menunjukkan nilai kadar gula.

\subsection{4. pH}

Pengukuran $\mathrm{pH}$ dilakukan kalibrasi terlebih dahulu dengan cara dengan cara memasukkan elektroda dari ph meter kedalam buffer pada ph 7, kemudian elektroda dibilas menggunakan aquades dan dikeringkan dengan tisu (Bloom , 1998). Elektroda yang telah dikalibrasi kemudian dimasukkan lagi ke dalam larutan sampel yang akan diuji, angka yang muncul pada layar ph meter ditunggu hingga konstan kemudian dicatat. Kemudian elektroda dibilas menggunakan sebelum dilakukan penentuan $\mathrm{pH}$ ke sampel selanjutnya dan melakukan kalibrasi kembali.

\subsection{Uji Organoleptic Kopi}

Teknis pengujian cita rasa kopi/cupping atau organoleptic dilakukan oleh panelis agak terlatih sebanyak 20 panelis

a. Disiapkan biji kopi yang telah diroasting sebanyak 5 gram kedalam masingmasing gelas.

b. Dilakukan pengecilan ukuran biji kopi dari setiap mangkok cupping menggunakan grinder dengan ukuran 20 mesh

c. Dilakukan pembauan untuk menilai aroma kopi sebelum di seduh atau fragrance.

d. Diseduh kopi menggunakan $150 \mathrm{ml}$ air panas suhu $93^{\circ} \mathrm{C}$ dan dibiarkan selama 4 menit (metode tubruk)

e. Diaduk perlahan permukaan larutan kopi sambil mendekatkan hidung ke gelas cupping untuk mendapatkan aroma atau break.

f. Dihilangkan buih dan bubuk kopi yang terapung pada permukaan larutan dengan menggunakan dua sendok.

g. Diseruput kopi setelah suhu mencapai $70^{\circ} \mathrm{C}-73^{\circ} \mathrm{C}$ dan dilakukan penlian pada form SCAA.

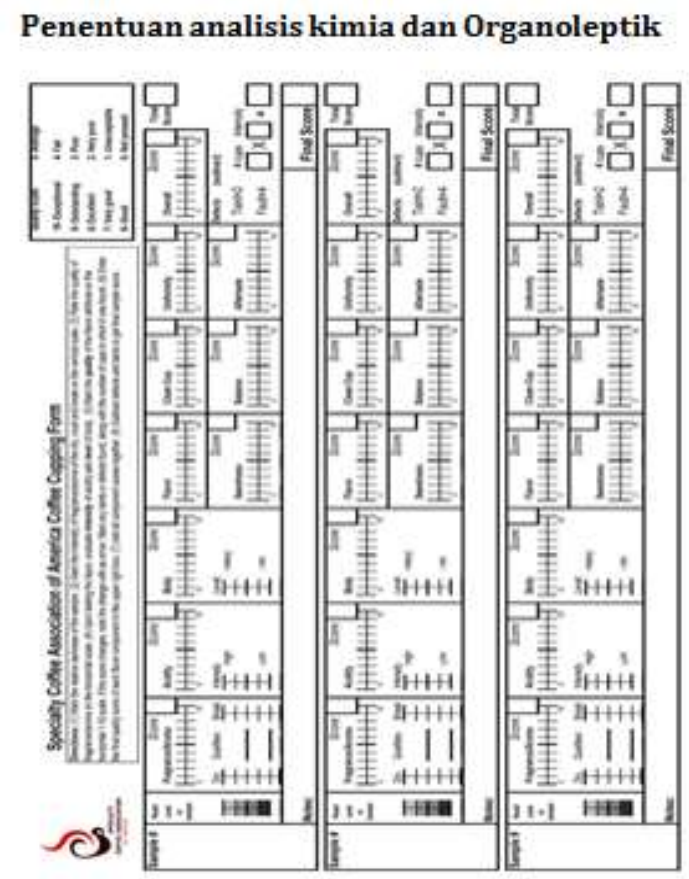

Gambar 2. Formulir Penilaian Uji Organoleptic dari SCAA 


\section{HASIL DAN PEMBAHASAN}

\subsection{Kadar Air Biji Kopi}

Kadar air adalah jumlah air yang terkandung didalam suatu bahan. Uji kadar air untuk mengetahui kualitas dan mutu kopi bubuk yang dihasilkan. Dari Tabel 1 terlihat tingkat kematangan buah dan intensitas pencucian berpengaruh nyata terhadap kadar air bubuk kopi yang dihasilkan. Kadar air tertinggi sebesar $5,37 \%$ terdapat pada sampel buah kopi tanpa pencucian dan buah matang. Buah matang optimal memiliki kandungan air lebih tinggi dan mucilage lebih tebal yang kaya akan gula yang bersifat hidroskopis atau mudah menyerap air dari lingkungan sehingga Perlakuan tanpa pencucian atau black honey memiliki kadar air lebih tinggi dibandingkan perlakuan lainnya. Menurut (Lee, 2002) buah lewat matang mengalami penurunan kadar air mencapai 50\%. Hal tersebut yang menyebabkan kadar air buah lewat matang lebih kecil dibandingkan buah matang optimal. Setiap sampel produk hasil penelitian ini memenuhi syarat mutu kopi bubuk SNI 01-3542-2004 yaitu kadar air maksimal kopi bubuk sebesar 7\%.

\subsection{Kadar Abu}

Tujuan dilakukannya uji kadar abu adalah untuk mengetahui tinggi rendahnya nilai kadar abu dari bubuk kopi yang dihasilkan, semakin rendah kadar abunya maka semakin baik bubuk kopi tersebut. Semua perlakuan tidak menunjukkan beda nyata terhadap kadar abu, Komponen abu terdiri dari kalsium dan magnesium, sehingga dengan semakin meningkatnya kandungan mineral berupa kalsium dan magnesium maka kadar abu akan semakin tinggi. Setiap sampel produk hasil penelitian ini memenuhi syarat mutu kopi bubuk SNI 01-3542-2004 yaitu kadar abu maksimal kopi bubuk sebesar $5 \%$.

\subsection{Kadar Gula Total}

Tinggi rendahnya kadar gula kopi dapat mempengaruhi karakteristik rasa dari kopi tersebut. Analisis kadar gula total dilakukan untuk melihat apakah kadar gula total mempengaruhi kualitas rasa pada uji organoleptik bubuk kopi prose honey.

Dari Tabel 3 terlihat perlakuan tanpa pencucian (black honey) berbeda nyata terhadap kadar gula total, dan intensitas 1 kali pencucian (yellow honey) dan 2 kali pencucian (red honey) tidak berpengaruh nyata terhadap gula total. Hal ini dikarenakan banyaknya mucilage yang tetap menempel dan terfermentasi bersama biji kopi pada saat penjemuran menyebabkan perlakuan tanpa pencucian (Black honey) memiliki kadar

Tabel 1. Hasil Uji Jarak Berganda Duncan (JBD) Analisis Nilai Kadar Air Bubuk Kopi Proses Honey (\%)

\begin{tabular}{ccccc}
\hline $\begin{array}{c}\text { Tingkat } \\
\text { Kematangan }\end{array}$ & $\begin{array}{c}\mathbf{B}_{\mathbf{1}} \\
(\text { Yellow })\end{array}$ & $\begin{array}{c}\mathbf{B}_{\mathbf{2}} \\
(\text { Red })\end{array}$ & $\begin{array}{c}\mathbf{B}_{3} \\
(\text { Black })\end{array}$ & Rerata A \\
\hline $\mathrm{A}_{1}$ (Mentah) & 3,75 & 4,07 & 4,32 & $4,05^{\mathrm{x}}$ \\
$\mathrm{A}_{2}$ (Matang) & 5,04 & 5,34 & 5,74 & $5,37^{\mathrm{y}}$ \\
$\mathrm{A}_{3}$ (Lewat Matang) & 4,87 & 5,24 & 5,31 & $5,14^{\mathrm{z}}$ \\
\hline Rerata B & $\mathbf{4 , 5 5 ^ { \mathbf { r } }}$ & $\mathbf{4 , 8 9 q}$ & $\mathbf{5 , 1 2} \mathbf{p}$ & \\
\hline
\end{tabular}

Keterangan: Rerata yang diikuti huruf yang berbeda dengan kolom maupun baris menunjukkan adanya perbedaan berdasarkan uji jarak berganda Duncan pada jenjang nyata 5\%.

Tabel 2. Hasil Uji Jarak Berganda Duncan (JBD) Analisis Nilai Kadar Abu Bubuk Kopi Proses Honey $(\%)$

\begin{tabular}{ccccc}
\hline $\begin{array}{c}\text { Tingkat } \\
\text { Kematangan }\end{array}$ & $\begin{array}{c}\mathbf{B}_{\mathbf{1}} \\
(\text { Yellow })\end{array}$ & $\begin{array}{c}\mathbf{B}_{\mathbf{2}} \\
(\text { Red })\end{array}$ & $\begin{array}{c}\mathbf{B}_{\mathbf{3}} \\
(\text { Black })\end{array}$ & Rerata A \\
\hline $\mathrm{A}_{1}$ (Mentah) & $2,4858^{\mathrm{b}}$ & $3,0968^{\mathrm{b}}$ & $3,1861^{\mathrm{b}}$ & 2,9229 \\
$\mathrm{~A}_{2}$ (Matang) & $3,2639^{\mathrm{b}}$ & $3,3553^{\mathrm{b}}$ & $3,5177^{\mathrm{b}}$ & 3,3789 \\
$\mathrm{~A}_{3}$ (Lewat Matang) & $4,5856^{\mathrm{a}}$ & $4,1569^{\mathrm{a}}$ & $4,3564^{\mathrm{a}}$ & 4,3663 \\
\hline Rerata B & $\mathbf{3 , 4 4 5 1}$ & $\mathbf{3 , 5 3 6 3}$ & $\mathbf{3 , 6 8 6 7}$ & \\
\hline
\end{tabular}

Keterangan: Rerata yang diikuti huruf yang berbeda dengan kolom maupun baris menunjukkan adanya perbedaan berdasarkan uji jarak berganda Duncan pada jenjang nyata $5 \%$. 
gula total lebih tinggi dibandingkan perlakuan dengan 2 kali pencucian (Yellow honey).

Kematangan buah pada semua perlakuan berbeda nyata terhadap gula total. Buah lewat matang memiliki nilai kadar gula total tertinggi yaitu sebesar 3,2342\% dan buah mentah memiliki kadar gula total terendah yaitu sebesar 2,3268\%. Menurut Selmar et al., (2008), mucilage atau daging buah kopi mengandung gula sederhana dalam bentuk glukosa, fruktosa, serta beberapa asam amino bebas dan air. Kadar gula didalam mucilage akan meningkat dengan cepat selama proses pematangan buah, menyebabkan buah kopi yang matang akan terasa manis. Hasil dari proses degradasi atau pemecahan sukrosa dan komponen gula yang terkandung pada daging buah kopi (mucilage) akan menghasilkan berbagai komponen senyawa asam diantaranya asam laktat dan asam butirat dan propionate, dan beberapa senyawa alcohol seperti etanol (Alvalone et al., 2011).

\subsection{Nilai pH}

Uji nilai $\mathrm{pH}$ bertujuan untuk mengetahui tinggi rendahnya nilai $\mathrm{pH}$ dari bubuk kopi yang dihasilkan dan diseduh. Semakin rendah nilai $\mathrm{pH}$ nya maka semakin tinggi tingkat keasaman kopi tersebut. Perbedaan intensitas pencucian dan tingkat kematangan buah kopi berpengaruh terhadap nilai $\mathrm{pH}$, tetapi tidak menunjukkan adanya interaksi antara intensitas pencucian dan tingkat kematangan buah kopi terhadap nilai pH.

Intensitas pencucian (black honey) tanpa pencucian berbeda nyata terhadap $\mathrm{pH}$ bubuk kopi yang dihasilkan, sementara intensitas pencucian 1 kali (yellow honey) dan intensitas pencucian 2 kali (red honey) tidak menunjukkan beda nyata terhadap pH bubuk kopi. Intensitas pencucian yang berbeda akan mempengaruhi jumlah lapisan mucilage yang menempel pada permukaan kopi. Pada proses Black honey atau tanpa pencucian, banyaknya jumlah mucilage yang melekat pada permukaan biji membutuhkan waktu yang lebih lama dalam pengeringannya dibandingkan red dan yellow honey. Selama pengeringan terjadi proses fermentasi. Redgwell dan Fischer (2006) serta Lin (2010) menyatakan bahwa pada proses fermentasi terjadi penguraian karbohidrat oleh aktivitas enzim karbohidratase dan enzim pektinase menjadi gula reduksi seperti glukosa dan fruktosa. Selain itu pada proses fermentasi terjadi penguraian senyawa karbohidrat menjadi asam-asam organik seperti asam laktat dan asam asetat, yang ditandai dengan penurunan pH (Avallone et al., 2002; Jackels dan Jackels, 2005; Rubiyo et al., 2005; Lin, 2010).

Tabel 3. Hasil Uji Jarak Berganda Duncan (JBD) Analisis Nilai Kadar Gula Total Bubuk Kopi Proses Honey (\%)

\begin{tabular}{ccccc}
\hline $\begin{array}{c}\text { Tingkat } \\
\text { Kematangan }\end{array}$ & $\begin{array}{c}\mathbf{B}_{\mathbf{1}} \\
(\text { Yellow })\end{array}$ & $\begin{array}{c}\mathbf{B}_{\mathbf{2}} \\
(\text { Red })\end{array}$ & $\begin{array}{c}\mathbf{B}_{3} \\
(\text { Black })\end{array}$ & Rerata A \\
\hline $\mathrm{A}_{1}$ (Mentah) & 2,1646 & 2,1833 & 2,6326 & $2,3268^{\mathrm{x}}$ \\
$\mathrm{A}_{2}$ (Matang) & 2,5662 & 2,7657 & 2,8988 & $2,7435^{\mathrm{y}}$ \\
$\mathrm{A}_{3}$ (Lewat Matang) & 3,2072 & 3,2163 & 3,2791 & $3,2342^{\mathrm{z}}$ \\
\hline Rerata B & $\mathbf{2 , \mathbf { 6 4 6 0 } ^ { \mathrm { b } }}$ & $\mathbf{2 , 7 2 1 7 ^ { \mathbf { b } }}$ & $\mathbf{2 , 9 3 6 8 ^ { \mathrm { a } }}$ & \\
\hline
\end{tabular}

Keterangan : Rerata yang diikuti huruf yang berbeda dengan kolom maupun baris menunjukkan adanya perbedaan berdasarkan uji jarak berganda Duncan pada jenjang nyata $5 \%$.

Tabel 4. Hasil Uji Jarak Berganda Duncan (JBD) Analisis Nilai pH Bubuk Kopi Proses Honey

\begin{tabular}{lcccc}
\hline $\begin{array}{c}\text { Tingkat } \\
\text { Kematangan }\end{array}$ & $\begin{array}{c}\mathbf{B}_{\mathbf{1}} \\
(\text { Yellow })\end{array}$ & $\begin{array}{c}\mathbf{B}_{\mathbf{2}} \\
(\text { Red })\end{array}$ & $\begin{array}{c}\mathbf{B}_{\mathbf{3}} \\
(\text { Black })\end{array}$ & Rerata A \\
\hline $\mathrm{A}_{1}$ (Mentah) & 4,61 & 4,62 & 4,13 & $4,45^{\mathrm{z}}$ \\
$\mathrm{A}_{2}$ (Matang) & 5,17 & 4,99 & 4,65 & $4,93^{\mathrm{y}}$ \\
$\mathrm{A}_{3}$ (Lewat Matang) & 5,31 & 5,28 & 5,13 & $5,24^{\mathrm{x}}$ \\
\hline Rerata B & $5,03^{\mathrm{p}}$ & $4,96 \mathrm{p}$ & $4,63^{\mathrm{q}}$ & \\
\hline
\end{tabular}

Keterangan: Rerata yang diikuti huruf yang berbeda dengan kolom maupun baris menunjukkan adanya perbedaan berdasarkan uji jarak berganda Duncan pada jenjang nyata $5 \%$. 
Tabel 5. Nilai Rata-rata Hasil dari Seluruh Uji Organoleptik Kopi Bubuk Hasil Proses Madu (Honey Proses)

\begin{tabular}{lcccc}
\hline \multicolumn{1}{c}{ Perlakuan } & Aroma & Body & Acidity & Flavour \\
\hline tensitas Pencucian & & & & \\
2 x pencucian (yellow honey) & 7,27 & 7,55 & 7,52 & 6,93 \\
1 x pencucian(Red honey) & 7,51 & 8,14 & 7,64 & 7,61 \\
Tanpa pencucian (black honey) & 7,29 & 8,16 & 7,71 & 7,91 \\
\hline ngkat kematangan & & & & \\
Buah Kopi Mentah & 6,54 & 6,60 & 6,48 & 6,35 \\
Buah kopi Matang & 7,80 & 8,47 & 8,10 & 8,21 \\
Buah kopi Lewat matang & 7,74 & 8,78 & 8,29 & 7,89 \\
\hline
\end{tabular}

Tingkat kematangan buah berbeda nyata pada semua perlakuan terhadap nilai $\mathrm{pH}$ kopi yang dihasilkan, kopi mentah memiliki pH 4 sedangkan buah kopi lewat matang memiliki nilai pH 6 yang menandakan bahwa semakin tinggi tingkat kematangan buah kopi maka semakin berkurang keasamannya. Menurut Selmar et al (2008), buah kopi mengandung gula sederhana seperti glukosa, fruktosa dan protein dalam bentuk asam amino, seiring dengan bertambahnya kematangan buah maka jumlah gula-gula akan meningkat dan menghasilkan rasa manis pada buah kopi matang, sedangkan asamasam organic dan senyawa fenolik akan mengalami penurunan yang mengakibatkan rasa sepet dan masam berkurang, nilai $\mathrm{pH}$ akan bertambah hingga buah kopi tersebut matang (Apandi, 1984).

\subsection{Uji Oraganoleptik Kopi Proses Madu (Honey Proses)}

Uji organoleptik menggunakan penilaian kesukaan dari 1 sampai 8. Dimana nilai 1 sangat tidak suka, 2 tidak suka, 3 agak tidak suka, 4 netral, 5 agak suka, 6 suka, 7 sangat suka, 8 excelent.

\subsubsection{Aroma}

Tingkat pencucian (red) 1 kali pencucian menghasilkan nilai organoleptic aroma tertinggi, hal ini dipengaruhi oleh tingkat keasaman yang tidak terlalu rendah sehingga aroma yang dihasilkan lebih disukai, dibandingkan perlakuan tanpa pencucian (black honey) yang memiliki aroma lebih asam.

Buah matang optimal memiliki nilai organoleptik aroma tertinggi, sedangkan nilai kesukaan terendah terhadap aroma ada pada perlakuan buah mentah yang menandakan bahwa buah yang dipetik pada saat matang optimal lebih disukai aromanya dibandingkan buah yang petik hijau (mentah). Pembentukan jumlah zat volatil juga dipengaruhi oleh kematangan buah, menurut Sedgey dan Griffin (1989) pematangan biasanya meningkatkan zat-zat atsiri, yang mana termasuk golongan senyawa volatil, yang dapat mempengaruhi aroma dan rasa.

\subsubsection{Body}

Body merupakan tingkat kekentalan kopi yang dirasakan oleh lidah saat menyeruput kopi. Perlakuan tanpa pencucian (black honey) menghasilkan body yang tinggi diantara perlakuan lainnya. Pengaruh perlakuan persen kandungan mucilage menunjukkan bahwa semakin banyak persen mucilage yang ikut dijemur bersama dengan biji maka semakin kuat Body nya. Komposisi kimia yang terkandung didalam kopi dapat mempengaruhi kuat atau lemahnya body pada kopi seperti lemak dan karbohidrat yang terkandung didalam buah kopi. Tinggi rendahnya kandungan minyak didalam buah kopi dipengaruhi oleh kondisi buah kopi tersebut, seiring pematangan buah kopi maka semakin kompleks senyawa kimia termasuk karbohidrat dan minyak yang ada didalamnya (Teguh, et al, 2016). Hal tersebut yang mengakibatkan body perlakuan buah kopi lewat matang lebih disukai. Buah kopi dengan tingkat kematangan lewat matang memiliki nilai organoleptik body tertinggi, dibandingkan buah matang dan buah mentah, sedangkan buah mentah jauh lebih rendah nilai kesukaannya terhadap body yang menandakan bahwa buah yang dipetik pada saat mentah sangat lemah body-nya. 


\subsubsection{Acidity}

Acidity pada kopi merupakan rasa asam yang enak, atau rasa asam yang tidak enak. Acidity yang baik seperti rasa buah segar yang langsung terasa saat kopi diseruput. Sebaliknya acidity yang terlalu dominan adalah rasa asam yang tidak enak. Acuan acidity yang digunakan oleh cup taster biasanya mengacu pada kopi Kenya yang mempunyai acidity yang tinggi dan kopi Sumatera dengan acidity yang rendah.

Perlakuan tanpa pencucian (black honey) menghasilkan acidity yang paling disukai diantara perlakuan lainnya. Pengaruh perlakuan persen kandungan mucilage menunjukkan bahwa semakin banyak persen mucilage yang ikut dijemur bersama dengan biji maka semakin disukai dari segi acidity nya. Hal ini dikarenakan persen mucilage yang terbanyak memiliki nilai kadar gula yang tertinggi, sehingga menutupi sebagian rasa asam pada seduhan kopi. Hal ini didukung oleh penelitian (Lingle, 2011), yang menyatakan bahwa asam-asam meningkatkan rasa sweetness (kemanisan) dari gula dan gulagula mengurangi rasa keasaman dari asam-asam, oleh karena itu tingginya kandungan gula dapat menyamarkan rasa asam yang ada.

Tingkat kematangan buah kopi lewat matang memiliki nilai organoleptik acidity tertinggi, dibandingkan buah matang dan buah mentah, sedangkan buah mentah jauh lebih rendah nilai kesukaannya terhadap acidity yang menandakan bahwa buah yang dipetik pada saat mentah sangat lemah acidity. Acidity disini diartikan bukan hanya tinggi rendahnya tingkat rasa asam. Tetapi yang menjadi para meter yaitu asam yang enak, dan bisa di terima. Nilai acidity perlakuan mentah yaitu rendah nilai acidity-nya dikarenakan rasa asam yang tidak disukai. hasil analisis nilai $\mathrm{pH}$, yang menunjukkan bahwa perlakuan kopi mentah memilik asam yang lebih tinggi. Beberapa panelis lebih suka rasa asam yang tidak terlalu tinggi. Menururt Teguh, et al, (2016) acidity yang terlalu tinggi atau terlalu dominan dapat menjadi tidak enak. Oleh karena itu perlakuan kopi lewat matang dan matang optimal lebih disukai dan berbeda nyata terhadap acdity-nya dibandingkan dengan perlakuan buah mentah.

\subsubsection{Flavor}

Perlakuan tanpa pencucian (black honey) menghasilkan flavor yang paling disukai diantara perlakuan lainnya. Dengan mempertahankan kandungan mucilage diperumukaan biji kopi dan ikut terjemur bersama dengan biji selama proses pengeringan flavour yang terbentuk panling disukai oleh panelis. Hal ini dikarenakan persen mucilage yang terbanyak memiliki protein, gula dan mineral yang lebih tinggi menyebabkan proses fermentasi yang terjadi lebih maksimal, sehingga menimbulkan rasa buah buahan matang yang lebih kompleks dibandingkan perlakuan lainnya. Hasil penelitian ini menunjukkan adanya perbedaan antar perlakuan persen mucilage terhadap kuat atau lemahnya flavor kopi yang dihasilkan. Tingkat kematangan buah kopi juga mempengaruhi flavor. Buah kopi matang optimal memiliki nilai organoleptik flavour tertinggi dan memiliki rasa manis yang stabil, diikuti buah lewat matang dan flavor terendah ada pada buah mentah. buah lewat matang mengeluarkan rasa stink, flat karena sudah kehilahangan rasa khas, dan sebagian rasa buah buah busuk.

\section{KESIMPULAN}

Tingkat kematangan berpengaruh terhadap kadar air, kadar gula total, $\mathrm{pH}$ tetapi tidak berpengaruh terhadap kadar abu. Intensitas pencucian berpengaruh terhadap kadar air, kadar gula total, $\mathrm{pH}$, tetapi tidak berpengaruh terhadap kadar abu. Jika dilihat hasil uji organoleptik bahwa yang paling disukai yaitu pada sampel $\mathrm{A}_{2} \mathrm{~B}_{3}$ yaitu buah kopi matang optimal yang diolah tanpa dilakukannya pencuncian (black honey). Seluruh perlakuan dari penelitian ini memenuhi syarat mutu bubuk kopi kopi yaitu SNI 01-3542-2004, ditinjau dari kadar air dan kadar abunya.

\section{DAFTAR PUSTAKA}

Avallone, S., J. M. Brillouet, B., Guyot, E., Olguin, and J. P. Guiraud. 2002. Involvement of pectolytic microorganisms in coffee fermentation. International Journal of Food Science and Technology, 37: 191198. 
[BPS] Badan Pusat Statistik. 2017. SNI 01-35422004. Retrieved 20/1/2020, from Badan Pusat Statistik (BPS), Jakarta. https:// jdih.bsn.go.id/public_assets/file/ 189c126396241a7428ce21071dd4c92d.

[BPS] Badan Pusat Statistik. 1992. SNI 01-28911992. Retrieved 15/7/2020, from Badan Pusat Statistik (BPS), Jakarta. http://sispk.bsn.go.id/SNI/DetailSNI/ 3258

[BSN] Badan Standar Nasional. 2008. SNI 012907-2008. Retrieved 10/7/2020, From Badan standar Nasional (BSN), Jakarta. https://bsn.go.id/uploads/download/ 3._SNI_produk_ekspor_SulSel_Kabid_PPK_1.pdf

Bloom, J. H. 1998. Chemical and phusical Water quality Analysis A Report and Practical at Training at Faculty of Fisheries. Universitas Brawijaya, Malang.

Bradley, R. L. 2010. Moisture and total solids analysis. In Food analysis (pp. 85-104). Springer, Boston, MA.

Brollo, G., R. Cappucci, and L. Navarini 2008. Acidity In: Coffee : Bridging the Gap between Chemistry and Psychophysics. Proc. 22 th International Confrence on Coffee Science 2008. Campinas, Brazil, 270-280.

Buffo, R. A. and C. C. Freire. 2004. Coffee flavour: an overview. Flavour and Fragrance Journal, 19: 99-104.

Griffin, A,. R., dan Sedgley, M.1989. Sexsual Reproduction of Tree Crops. Academic Press Inc. San Diego. Harcourt Brace Jovanovich Publishe

Harsono, S.S. Salahuddin., M. fauzi., G.S. Purwono., D. Sormarno., Kissinger. 2015. Second Generation Bioethanol From Arabica Coffee Waste processing at smallholder Plantation In Ijen Plateau region Eastjava. Publish by Elsivier, doi:10.1016/ j.proche.2015.03.055
Lee, C. 2002. Green Coffee Storage: A Factor that Ought Not to be Overlooked from Tea and Coffee Trade Journal. Feb 1999. Sweet Maria Com., 1 p.

Lin, 2010. Approach of Improving Coffee Industry in Taiwan-Promote Quality of Coffee bean by Fermentation. The Journal of International Managemen Studies, 5 (1):154-159

Lingle, T.R. 2001. The Coffee Cupper's Handbook; A Systematic Guide to the Sensory Evaluation of Coffee's Flavor. 3rd Ed. Coffee Development Group, Washington D.C. 71 p.

Madigan, M. Martinko, J. 2016. Brock Biology of Microorganisms, Eleventh Edition. Pearson Prentice Hall,Inc

Mulato, S., dan Suharyanto, E. 2012. Kopi, Seduhan dan Kesehatan. Pusat Penelitian Kopi dan Kakao Indonesia, Jember.

Ottencoffee, 2018. Retrieved 15/9/2020 https:/ /majalah.ottencoffee.co.id/bagaimanafermentasi-biji-kopi-mempengaruhirasa-kopi/.

Redgwell, R. and M. Fischer. 2006. Coffee carbohidrates. Brazilian Journal of Plant Physiology, 18 (1): 165-174.

Ridwansyah, 2003. Pengolahan Kopi. Jurusan Teknologi Pertanian. Fakultas Pertanian, Universitas Sumatera Utara.

Selmar, D., G. Bytof, S. E. Knopp, A. Bradbury, J. Wilkens and R. Becker. 2004. Biochemical insight into coffee processing: quality and nature of green coffees are interconnected with an active seed metabolism. ASIC 2004. 20th International Conference on Coffee Science, Bangalore, India, 11-15 October 2004. p. 111-119.http:// www.cabdirect.org/.

Settanni. L, O. Massitti, D. Van Sinderen, S. Corsetti. 2005. In Situ Activity of 
Bacteriocin-Producing Lactococcus lactis strain. Influence on Interactions Between Lactic Acid Bacteria during Sourdough Fermentation. https://doi.org/10.1111/ j.1365-2672.2005.02647.x

Susan C. Jackels, Charles F. Jackels. 2006. Characterization of the Coffee Mucilage Fermentation Process Using Chemical
Indicators: A Field Study in Nicaragua. https://doi.org/10.1111/j.13652621.2005.tb09960.x

Teguh, W., Pujianto, dan Misnawi. 2016. Kopi: Sejarah Botani, Proses Produksi, Pengolahan, Produk Hilir, dan Sistem kemitraan. UGM Press. Yogyakarta 